\title{
Histomorphometric Assessment of Pentachlorophenol Toxic Effects on the Freshwater Snail Holandriana holandrii
}

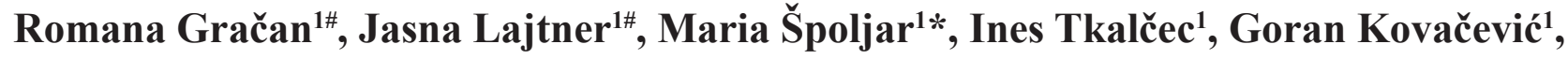 \\ Blaženka Banjad Ostojić ${ }^{1,2}$, Martina Ivšić ${ }^{1}$, Ana Miletić ${ }^{1,3}$, Radovan Erben ${ }^{1}$ \\ ${ }^{1}$ Division of Zoology, Department of Biology, Faculty of Science, University of Zagreb, \\ Rooseveltov trg 6, HR-10000 Zagreb, Croatia \\ ${ }^{2}$ Institut IGH, Janka Rakuše 1, HR-10000 Zagreb, Croatia \\ ${ }^{3}$ Association for Nature, Environment and Sustainable Development SUNCE, \\ Obala Hrvatskog Narodnog Preporoda 7, HR-21000 Split, Croatia
}

Received: 29 July 2021

Accepted: 16 October 2021

\begin{abstract}
The pollution of aquatic ecosystems by sodium pentachlorophenolate (Na-PCP) has assumed serious proportions due to their toxicity and accumulative effect in organisms and environment. The objective of this experimental study was to examine and quantify the histopatological effects of Na-PCP on the structure of hepatopancreas and gill, as two most important organs targeted by phenol entries, in the freshwater snail, Holandriana holandrii. Results indicate serious structural changes in tissue and epithelial cells of both organs and were accelerated with increase of Na-PCP concentrations and more pronounced related to exposed period. In hepatopancreas, tubular lumen, vacuole surface and number per tubule, exudate area in the tubular lumen, all increased with increase in concentration. Opposite trend of decreased height was observed for digestive and basophil cells. Significant gill structural changes appeared as a progressive necrosis at epithelial cells and the epithelial lining was interrupted, while connective tissue exhibited vacuolization, formation of large irregular spaces and damaged chitinous rods. Histomorphometrical approach in quantification of toxicant effects on the organism tissue could be used in legislative prevention of hazardous effects in freshwater ecosystems and $H$. holandrii may serve as a reliable and sentinel indicator of freshwater deterioration.
\end{abstract}

Keywords: gill, hepatopancreas, tissue and cell measurement, vacuolisation, digestive and basophile cells

\#Equal contributors, they are co-first authors.

*e-mail: maria.spoljar@biol.pmf.hr 


\section{Introduction}

A large amount of wastewaters has an impact on the natural balance among physical-chemical features and biological aspects in freshwater ecosystems. Many xenobiotics are the greatest threat to aquatic ecosystems, as they are rarely biodegradable and therefore accumulate in the environment or bioaccumulate through the food chain. Toxicity is visible in histopathological, biochemical or physiological deviations, and reflects animal growth, development, reproduction and behavior [1-3]. For a comprehensive understanding of toxicological tests, studies are extended on multiple levels of biological organization and the detection of histopathological changes ought to be analyzed both qualitatively and quantitatively [4]. Histomorphometry is standardised method for numerical objectivization of tissue features and can be used to acquire a value of tissue damage caused by toxins in ecosystems, what is a way to establish early signs of effects of toxicity [4].

In this study, specimens of freshwater snail Holandriana holandrii (C. Pfeiffer, 1828) were treated with a sodium pentachlorophenolate (Na-PCP), effective biocide, soluble in water which accumulates in organisms, soil, sediment, water, air and food [5, 6]. Na-PCP is a sodium salt of pentachlorophenolate (PCP), the most famous representative of chlorophenols which are environmental pollutants introduced into the environment due to its wide and persistent applications as algaecides, bactericides, fungicides, herbicides, insecticides, molluscicides and as general disinfectant in many industries, agriculture and households [7, $8,9]$. Due to long-term use in agriculture and long accumulation in water bodies, research in Dongting Lake (NE China) showed concentration of PCP from 0.005 to $103.7 \mu \mathrm{g} \mathrm{L}^{-1}$ in the water and much more in sediment, up to $48.3 \mu \mathrm{g} \mathrm{g}^{-1}$ [10]. In the floodplain region of Yamuna River (Delhi, India) phenolic compounds could reach range from 639 to $2112 \mu \mathrm{g} \mathrm{kg}^{-1}$ in soil, and from 553 to $20983 \mu \mathrm{g} \mathrm{kg}^{-1}$ in sediment [11]. PCP can be metabolized by numerous aquatic and soil microorganisms, but environmental conditions are usually unfavourable for biodegradation [7]. The histopathological research has shown high degree of pathological lesions observed in various organs, e.g., gills, liver, intestine and kidney of the fish Mystus vittatus caused due to excessive accumulation of phenolic compounds [12]. Furthermore, PCP also act both directly or indirectly on the metabolism of lipids as shown on coelomocytes earthworm Eisenia fetida [13], carbohydrates and proteins, as well as on the ion transport across the cell membrane [14]. These conditions lead to glycolysis and accumulation of lactic acid resulting in acidification of cells. Low $\mathrm{pH}$ inside cell stimulates release of the lysosomal enzymes causing further histopathological changes [7]. Most of the degenerative changes in cells are consequence of the inability of correcting the ion balance because due to the inhibition of a $\mathrm{Na} / \mathrm{K}$ pump the constant entrance of ions $\left(\mathrm{Na}^{+}, \mathrm{Cl}^{-}, \mathrm{Ca}^{2+}\right)$ and water is allowed which furthermore leads to cell vacuolization and swelling as well as to membrane damage in digestive gland by snail $H$. holandrii as observed in this study.

Molluscs accumulate quickly lipophilic organic matter and heavy metals and are quite easy to maintain in laboratory conditions [15]. Due to their semi-sessile lifestyle they are constantly exposed to unfavourable environmental conditions. However, the toxicity of PCP on aquatic organisms is well documented mostly on fish [6, 16] and crustaceans [17, 18], while only few published reports provide sensitivity of freshwater snail [1-3] or mussels [15, 19]. By terrestric snail, Helix aspersa, PCP inhibited growth of juvenile at a concentration of $1000 \mu \mathrm{g} \cdot \mathrm{g}^{-1}$ from the first week and at $500 \mu \mathrm{g} \cdot \mathrm{g}^{-1}$ from the fourth week of exposure [20].

Digestive and respiratory tracts are two most important routes of entry for toxicants, thus hepatopancreas and gill were selected as the targeted organs in this study. Molluscs' hepatopancreas is central metabolic organ involved in extracellular and intracellular food digestion, secretion of digestive enzymes, in storage of lipids and glycogen, as well as in detoxification [21, 22]. Accordingly, hepatopancreas is target organs in excretion of xenobiotics and highly recommended for physiological and toxicological studies $[22,23]$. Structural changes within hepatopancreas are visible in blind-ending tubules, encircled by thin layer of connective tissue, which consist of single layer epithelium with two cell types, digestive and basophilic cells [24]. Similarly, due to their large surface and direct contact with water, gills are particularly sensitive organ for water-borne pollutants. As a multifunctional organ, responsible for respiration and maintaining the optimal osmotic pressure and acid-base balance, gills exposed to chemicals exhibit severe changes in structure and consequently, have highly reduced capacity [25]. Toxicological damage may be visible in gills along series of leaflets, covered with epithelial cells, and underlying connective tissue with hemolymph spaces and supporting skeletal rods [2].

Freshwater snail $H$. holandrii inhabits streams, rivers and lakes of the Balkan Peninsula, and Danube River [26]. In aquatic ecosystems and food webs it is an important scraper over periphyton and food source for many vertebrates, i.e., fish. The objective of this study was to examine and quantify the histopatological effects of higher Na-PCP concentration on the hepatopancreas and gill as two most important organs target by phenol enters in the snail as reliable indicator of freshwater environmental changes. We hypothesized that measurement of histopathological changes could contribute to predict the threshold of Na-PCP concentration critical for changes which indicate mortality and certain decrease in $H$. holandrii population, as well as food web disconecting in the freshwater ecosystem. 


\section{Material and Methods}

In this study a snail $H$. holandrii was used as a test organism. Snails were collected from wild populations in the littoral zone of the urban Jarun Lake, situated in Zagreb (North-West Croatia, Europe). Animals were collected and acclimatised to laboratory conditions in dechlorinated tap water for $48 \mathrm{~h}$. Animals were divided into four containers (10 animals in each), three containers with test solutions and one control group were set up in triplicates, and no food was supplied during the experiment.

Snails were kept in containers in $1.5 \mathrm{~L}$ dechlorinated tap water, and exposed to toxic substance, sodiumpentachlorphenolate (Na-PCP, BDH Chemicals, Ltd, Poole, UK $89 \%$ technical purity, $\mathrm{Mr}\left(\mathrm{C}_{6} \mathrm{Cl}_{5} \mathrm{ONa}\right)$ $=288.32$ ). Based on the results of a preliminary mortality test three experimental concentrations were chosen: low concentrations (LC) 0.56, medium concentrations (MC) 1.00 and high concentrations (HC) $5.60 \mathrm{mg} \mathrm{L}^{-1} \mathrm{Na}-\mathrm{PCP}$. We designed a semi-static exposure regime, performed during $96 \mathrm{~h}(12 \mathrm{~h}$ light following $12 \mathrm{~h}$ dark), with test solutions replaced by fresh ones of the same respective concentrations every $24 \mathrm{~h} \mathrm{[27].}$

Each day of the experiment live specimens were removed from all three concentrations and control,

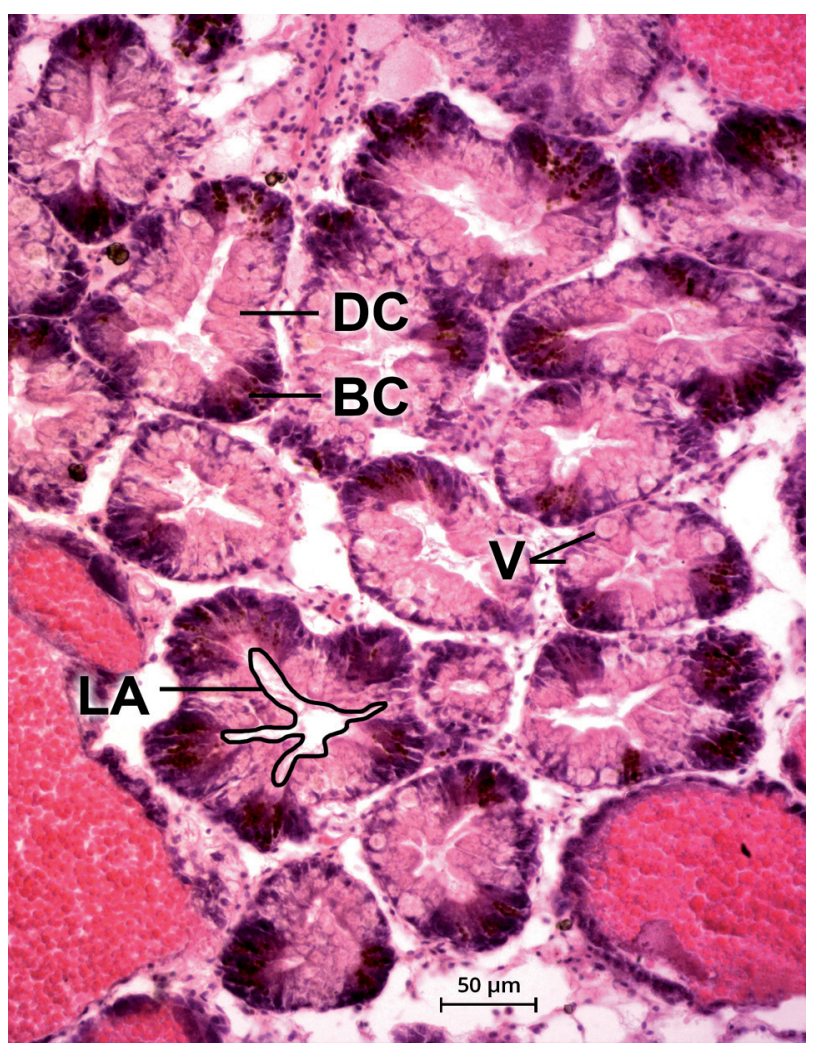

Fig. 1. Representative hepatopancreas tissue of Holandriana holandrii in control group with marked features analysed after exposure to Na-PCP. Abbreviation: height of DC - digestive cell and BC - basophilic cell, LA - tubular lumen area, TA - tubular cells area, $\mathrm{V}-$ vacuoles number. anaesthetised in menthol and dissected for histological assessment. Entire specimens were fixed in aqueous Bouin's solution for $24 \mathrm{~h}$. Upon fixation, samples were dehydrated and processed for routine embedding in paraffin wax, cut with a rotating microtome and stained with Hematoxylin and Eosin (HE). Histological sections were observed under a light microscope (Nikon Eclipse E600) equipped with digital camera AxioCam ERc5s and analysed with computed program for image analysis ZEN2 lite software (Carl Zeiss Microscopy $\mathrm{GmbH}$, Germany).

Morphometrical analysis and target structures of hepatopancreas were defined and based on previous study [3]. In that study main histopathological changes were described (vacuolisation, tubular lumen, exudate). Histomorphometric measurements of hepatopancreas' tubules included: tubular cells area (TA), tubular lumen area (LA), exudate area (EA), height of digestive (DC) and basophilic cells (BC), vacuoles area (VA) and number of vacuoles per tubule (V; Fig. 1). To examine histological responses of gill to Na-PCP, measurements included covering epithelium width and underlaying connective tissue width within three different gill leaflets regions: the apex region (A), lateral region covered with ciliary cells (LR) and the middle region (MR) without ciliary cells (Fig. 2).

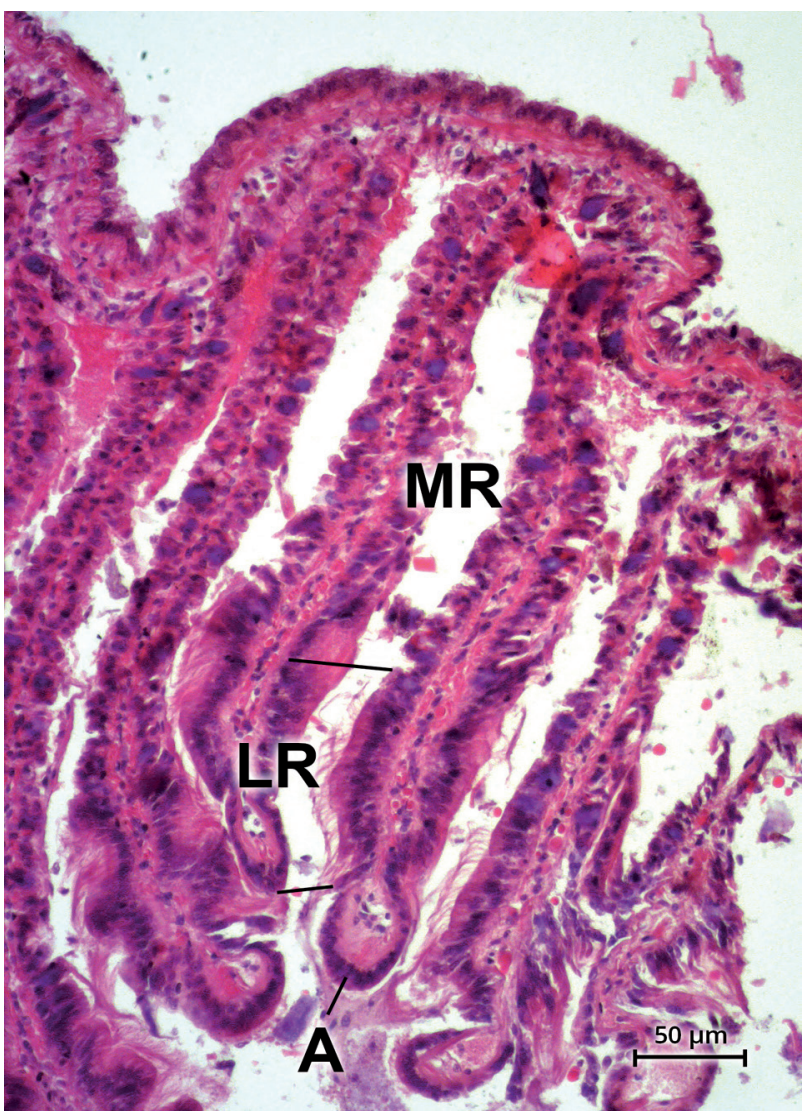

Fig. 2. Representative gill tissue of Holandriana holandrii in control group with three selected regions of interest and marked features analysed after exposure to Na-PCP. Abbreviation: MR middle region, $\mathrm{LR}$ - lateral region, $\mathrm{A}$ - apex region. 
Morphometric measurement during the $96 \mathrm{~h}$ of experiment set up did not show, because of impairment in comparison. Since histopathological changes gradually increase with the exposure period and appear earlier by higher concentration, gills exposed to the $\mathrm{HC}$ of Na-PCP after $48 \mathrm{~h}$ and $72 \mathrm{~h}$ were highly damaged and histomorphometrical analyses were not performed.

All statistical analyses were performed using IBM SPSS statistics for Windows, v.17 (IBM Corp) and results are shown as differences among test groups, i.e., Na-PCP concentrations. Variables which did not show normal distribution (One-Sample KolmogorovSmirnov Test, $\mathrm{p}<0.05$ ) were $\log$ transformed and compared between groups using one-way ANOVA. Tukey HSD post-hoc analysis was used for betweengroup comparisons. If log transformed data did not fit to normal distribution, nonparametric Kruskal-Wallis Test and Mann-Whitney Test were used. Analysis of covariance (ANOVA, $\mathrm{p}<0.05$ ) was performed to identify differences among treatments for three gill leaflets regions.

\section{Results}

\section{Histopathological Changes in the Hepatopancreas}

The hepatopancreas of control animals showed normal architecture, visible in numerous digestive tubules, separated by connective tissue and hemolymphatic spaces. The digestive epithelium was composed of digestive absorptive columnar cells filled with secretory granules and vacuoles and darkly stained shorter basophilic cells with calcite granules (Fig. 1). Snails exposed to the LC of Na-PCP $\left(0.56 \mathrm{mg} \mathrm{L}^{-1}\right)$ showed first histopathological signs of toxicity, visible in higher vacuolisation of epithelial cells, appearance of exudate in tubular lumen and widening of tubular lumen. More intense necrotic changes occurred when animals were exposed to MC of $1.00 \mathrm{mg} \mathrm{L}^{-1}$ of Na-PCP, with progressive vacuolisation, disruption of epithelium cells, erosion and shedding of epithelial cells into tubular lumen. Serious disorganisation of tubules and lysis of connective tissue was visible at $\mathrm{HC}$ of Na-PCP $\left(5.60 \mathrm{mg} \mathrm{L}^{-1}\right)$.

Table 1 and Fig. 3 present results of statistical analyses based on measured parameters in snail hepatopancreas. Tubular lumen was expanded and significantly differed between control and three groups exposed to Na-PCP (ANOVA, $p<0.001$ ). Surface of vacuoles within epithelia and surface of exudate area in lumen both significantly increased and differed between control and groups exposed to Na-PCP (ANOVA, $\mathrm{p}<0.001)$. Number of vacuoles per tubule increased rapidly with increase in concentration, and was significantly different between control and all groups exposed to toxic Na-PCP (ANOVA, $\mathrm{p}<0.001$ ). The most pronounced structural changes were recorded and statistically confirmed in group exposed to $\mathrm{HC}$ of Na-PCP: all measured variables were significantly different in comparison to lower concentrations of $\mathrm{Na}-$ PCP and control (ANOVA, all $\mathrm{p}<0.05$ ).

Oscillations of epithelial cell height i.e., digestive columnar and basophilic cells, were not significant (ANOVA, $\mathrm{F}=0.308, \mathrm{p}=0.820$ ). However, certain peculiarities occurred among each type of cells, appeared first as decrease in cell height between control and the LC (Mann-Whitney test $\mathrm{U}$ test, $\mathrm{Z}_{\mathrm{DC}}=-8.623$, $\left.Z_{B C}=-10.030 ; p<0.0001\right)$. For digestive cells height significant increase occurred by comparison between $\mathrm{MC}$ and $\mathrm{HC}$ (Mann-Whitney test $\mathrm{U}$ test, $\mathrm{Z}_{\mathrm{DC}}=-7.116$; $\mathrm{p}<0.0001)$. By basophilic cells trend of increase in cell height was more pronounced with increased Na-PCP concentration, LC and MC (Mann-Whitney U test, $\mathrm{Z}=-3.667, \mathrm{p}<0.001)$, and $\mathrm{MC}$ to the $\mathrm{HC}$ (Mann-Whitney $\mathrm{U}$ test, $\mathrm{Z}=-8.592, \mathrm{p}<0.05$ ), respectively (Fig. 3).

Table 1. The results of a) ANOVA $(\mathrm{p}<0.05)$ and $\mathrm{b})$ Kruskal-Wallis test $(\mathrm{p}<0.05)$ for significant histopathological changes among control and three experimental concentration groups in the hepatopancreas of Holandriana holandrii.

\begin{tabular}{|c|c|c|c|}
\hline a) & & \multicolumn{2}{|c|}{ ANOVA test } \\
\hline \multicolumn{2}{|r|}{ Features } & F & $\mathrm{p}$ \\
\hline \multicolumn{2}{|r|}{ Tubular Lumen Area (LA) } & 22.496 & $<0.001$ \\
\hline \multicolumn{2}{|r|}{ Exudate Area (EA) } & 18.853 & $<0.001$ \\
\hline \multicolumn{2}{|r|}{ Vacuoles Area (V) } & 59.491 & $<0.001$ \\
\hline \multicolumn{2}{|r|}{ Vacuoles per Tubule (VN) } & 62.599 & $<0.001$ \\
\hline b) & & Kruskal-Wallis test & \\
\hline \multicolumn{2}{|r|}{ Features } & $\mathrm{H}$ & $\mathrm{p}$ \\
\hline \multicolumn{2}{|r|}{ Height of digestive cell (DC) } & 166.76 & $<0.001$ \\
\hline \multicolumn{2}{|r|}{ Height of basophilic cells (BC) } & 182.81 & $<0.001$ \\
\hline
\end{tabular}



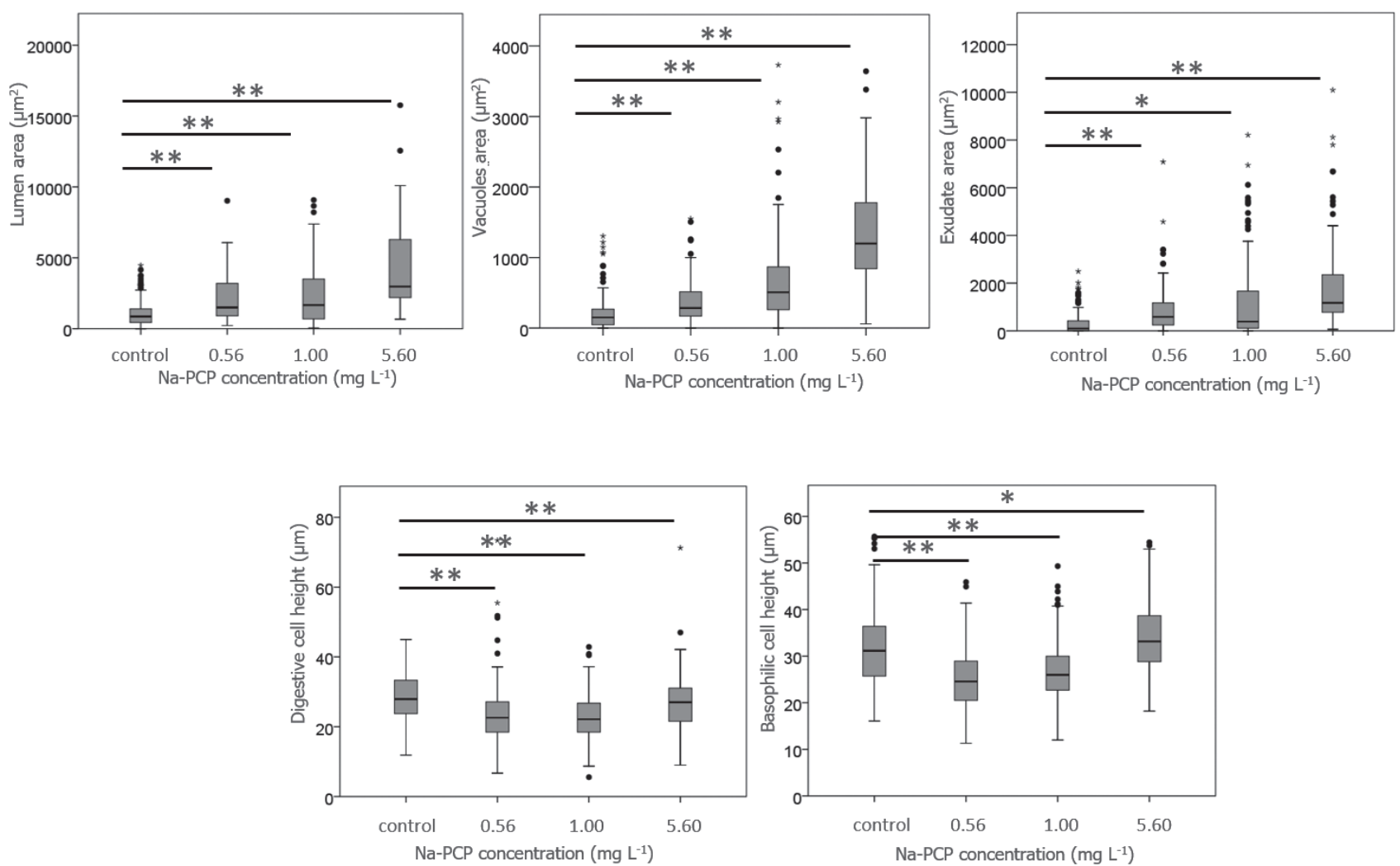

Fig. 3. Box-and-whisker plots of the measured histological structures in the digestive gland of Holandriana holandrii, after exposure to three experimental concentrations of Na-PCP. Boxes represent the 25 and 75th percentiles, while whiskers represent the minimum and maximum. Solid lines within boxes present the median values. * - indicates a significant difference between analysed groups and control $(* \mathrm{p}<0.05 ; * * \mathrm{p}<0.001)$.

\section{Histopathological Changes in the Gills}

Gills of control snails were composed of series of leaflets attached to the mantle wall. Epithelial cells covering leaflets were cuboid to columnar, with short cilia at the apex region and longer cilia at the lateral region. Connective tissue with hemolymph spaces and skeletal rods were visible in the inner space of leaflets (Fig. 2). Snails exposed to the LC of Na-PCP showed small changes in the gill structure: the cilia were not synchronised and cells started to transit into cuboidal shape. When animals were exposed to MC, epithelial cells started to swallow and change into cuboidal, with irregular spaces appearing in the underlying connective tissue. The HC of Na-PCP produced serious structural changes in the gills: signs of necrosis occurred at epithelial cells and the epithelial lining and were visible as interruptions (especially at the apex region), while connective tissue exhibited vacuolization, formation of large irregular spaces and damaged chitinous rods.

Both epithelial cell height and connective tissue width showed serious structural changes and significantly differed among experimental groups in all three analysed regions (Fig. 4, Table 2). Epithelial height measured within three different regions, showed significant difference among experimental groups exposed to different concentrations (ANOVA,
$\mathrm{F}=19.160, \mathrm{p}<0.001)$. Further on, measured connective tissue width within three different regions, followed the same pattern, and showed statistically significant difference among experimental groups exposed to different concentrations of Na-PCP and control (ANCOVA, $\mathrm{F}=14.321, \mathrm{p}<0.001$ ).

\section{Discussion}

In this study we quantitatively assessed histopathological changes on hepatopancreas and gills of freshwater snail $H$. holandrii, which likely occurred as a response on Na-PCP exposure, during the experimentally designed period of acute toxicity. Serious structural changes were visible, such as increase in vacuolisation of hepatopancreatic tubular epithelial cells, appearance of exudate in tubular lumen and widening of tubular lumen, while and epithelial cells of gills were swallowed and started to transit into cuboidal shape. Recently, more frequent extreme weather events (precipitations, soil leaching) and excessive application of pesticides could mitigate inflow of exceeded concentrations of toxic compounds in aquatic ecosystems. Thus, in this study we tested impact of higher Na-PCP concentrations $(0.56,1.00$ and $5.60 \mathrm{mg}$ $\mathrm{L}^{-1}$ ) to predict possible consequences, e.g., accidental 

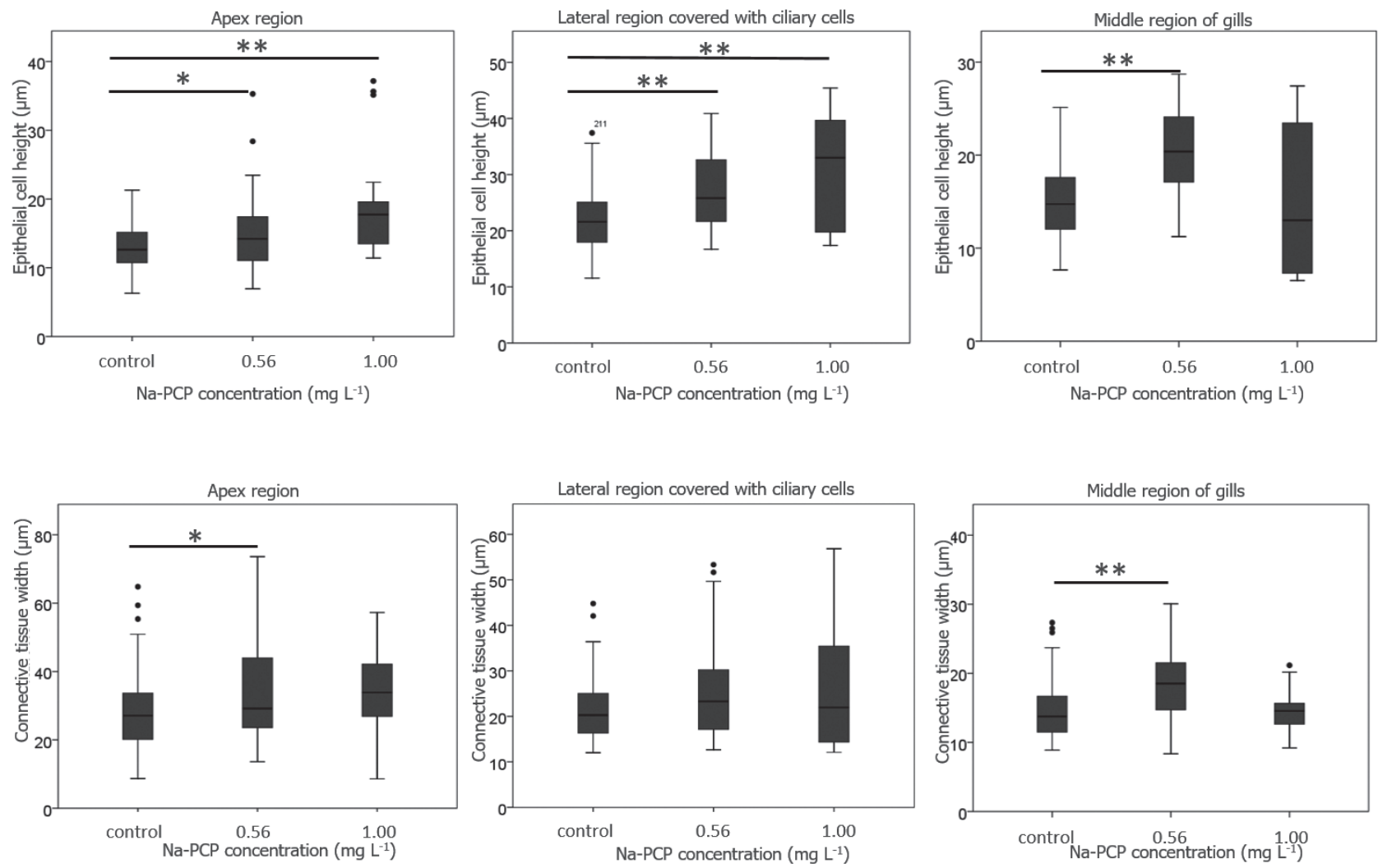

Fig. 4. Box-and-whisker plots of the measured histological structures in three selected regions in the gills of Holandriana holandrii, after exposure to three experimental concentrations of Na-PCP. Boxes represent the 25 and $75^{\text {th }}$ percentiles, while whiskers represent the minimum and maximum. Solid lines within boxes present the median values. * - indicates a significant difference between analysed groups and control $(* \mathrm{p}<0.05 ; * * \mathrm{p}<0.001)$.

discharge from chemical industry plants, leaching from the soil in the recent period of extreme weather events, on the aquatic community with an emphasis on the gastropods. Therefore, applied concentrations were higher than those which usually occur in the environment, $<0.01 \mu \mathrm{g} \mathrm{L}{ }^{-1} \mathrm{Na}-\mathrm{PCP}[7]$.

Table 2. The results of ANOVA test for significant histopathological changes in gills of Holandriana holandrii, among three experimental concentrations of $\mathrm{Na}-\mathrm{PCP}$ and control group.

\begin{tabular}{|c|c|c|}
\hline & \multicolumn{2}{|c|}{ ANOVA test } \\
\hline Features & $\mathrm{F}$ & $\mathrm{p}$ \\
\hline \multicolumn{3}{|c|}{ Epithelial Cell Height (EH) } \\
\hline Apical region & 12.313 & $<0.001$ \\
\hline Lateral region & 13.222 & $<0.001$ \\
\hline Middle region & 26.830 & $<0.001$ \\
\hline \multicolumn{3}{|c|}{ Connective Tissue Width (CT) } \\
\hline Apical region & 4.400 & 0.014 \\
\hline Lateral region & 2.069 & 0.130 \\
\hline Middle region & 13.824 & $<0.001$ \\
\hline
\end{tabular}

Expectedly, toxicological effects of Na-PCP on aquatic organism $H$. holandrii increased with the concentration and the duration of exposure, which was confirmed in other studies on aquatic organism, such as, molluscs: Mytilus galloprovincialis [19], Crassostrea gigas, Mytilus edulis, Ruditapes philippinarum and Chlamys farreri [16], crustaceans Palaemonetes pugio [18], and fish: Mystus vittatus [12] and Aristichthys nobilis [16].

During the experiment, animals underwent starvation, primarily to exclude impact of toxicant food web biomagnification. According to [27], it is considered that freshwater molluscs can survive without food for a longer period, and it won't impact the normal organism functioning.

PCP is moderately persistent in the soil environment, while in the water environment is mainly bound to sediments and suspended particles. Biodegradation occurs mainly at the water surface, with a half-life ranging from hours to days [28].

Digestive and respiratory system are two main entrances of toxicant into organisms with exoskeleton, such as snails [15] and crustaceans [29]. Otherwise, skin epithelium plays also important role in toxicant mediation, e.g. by fish [25] and amphibians $[28,29]$. The hepatopancreas is known as the most important organ for bioaccumulation of pesticides 
and other toxic substances like heavy metals in molluscs, e.g. [23, 30].

In this study, all the concentrations of Na-PCP caused significant histopathological and histomorphometrical changes in the gills and digestive gland of the exposed specimens. Those changes became more pronounced at highest concentrations of $5.60 \mathrm{mg} \mathrm{L}^{-1} \mathrm{Na}-\mathrm{PCP}$ and after $48 \mathrm{~h}$ resulted in tissue and organ functional destructions [3]. As a lipophilic substance, PCP easily accumulated in hepatopancreas tissue, and these results showed occurrence of histopathological changes already within $24 \mathrm{~h}$ in concentrations of 1.00 to $5.60 \mathrm{mg} \mathrm{L}^{-1}$. Vacuolar degeneration were noticed and vacuoles of various sizes significantly increased in relation to control. However, when we analysed histopathological differences within the same group exposed to the lowest concentration of $0.56 \mathrm{mg} \mathrm{L}^{-1} \mathrm{Na}-\mathrm{PCP}$, our results indicate that different changes occur, depending on the day of exposure. For instance, vacuolisation trend in the epithelial tubular cells first decreased after $48 \mathrm{~h}$, and then significantly increased after $72 \mathrm{~h}$ of exposure. Long term experiments with chronical exposure to toxicants are needed to further investigate these changes.

Similar effects of vacuolation were confirmed, with additional gathering of the amoebocytes in areas between tubules of the hepatopancreas, in the freshwater snail Galba truncatula exposed to organochloride pesticides Thiodan ${ }^{\circledR}$ [31] as numerous concretions in the metanephridium epithelium in freshwater snail Planorbarius corneus exposed to PCP [1]. At a lowest and medium concentrations of Na-PCP necrotic changes, i.e., exudation, widening of tubular lumen, necrosis of epithelial cells, occurred successively within $96 \mathrm{~h}$ exposure period. In an earlier report, $H$. holandrii developed histopathological lesions, such as epithelial necrosis in the hepatopancreas, firstly after $48 \mathrm{~h}$ of exposure to $1.00 \mathrm{mg} \mathrm{L}^{-1} \mathrm{Na}-\mathrm{PCP}$ [3].

Beside the exact measurement of structural changes, on the cellular level we noticed deformation which is probably related with enlargement of tubular lumen. Namely, both cell types, digestive and basophilic started to shrink through the exposure period. The disfunction of these cells leads to obstacles in digestion and calcite metabolism, important for the snail shell. Snail growth rates and densities are found to correlate positively with calcium availability [32]. Thinner shell makes them potentially easier pray for predators. Almost the similar changes were recorded in the gills, where epithelial cells started to change into cuboidal, with irregular spaces appearing in the underlying connective tissue after exposure to $1.00 \mathrm{mg} \mathrm{L}^{-1} \mathrm{Na}-\mathrm{PCP}$ and with signs of necrosis after exposure to $5.60 \mathrm{mg} \mathrm{L}^{-1} \mathrm{Na}-\mathrm{PCP}$. All three analysed gill regions show an increase in connective tissue damage. Our results are similar with findings of gill tissue necrosis observed after $48 \mathrm{~h}$ of exposure to 250 and $300 \mathrm{mg} \mathrm{L}^{-1}$ phenol in H. holandrii [2]. Histopathological findings are connected with biochemical and physiological changes in tissues, which altogether modify the organ's function [33]. Most gill damages occur on the gill epithelium directly due to the influence of the pollutants on the cells. Thus, asynchronous cilia schedule was observed probably as a consequence of destruction of ciliary mechanisms.

Histopathological changes caused by Na-PCP could be explained by decreasing in the quantity of ATP and increasing of inorganic phosphates, because of the interruption of oxidative phosphorylation $[34,35]$. PCP is lipophilic agent and thus easily penetrates in cell, including mitochondrial membranes, where hydrogen ions are being conducted through the inner mitochondrial membrane [13], and destroys the electrochemical potential and concentrations of energy provider adenosine triphosphate, ATP $[13,34,35]$. The deficit of ATP inhibits the $\mathrm{Na} / \mathrm{K}$ pump in the cell membrane, thus sodium ions and water are continuously entering the cell, leading to cell vacuolation, and successively to its degeneration [13].

\section{Conclusions}

In summary, histopathological and histomorphometric analyses of hepatopancreas and gill of snails treated with Na-PCP showed that most obvious changes were proportional to the amount of toxicant concentration and time of the exposure. Na-PCP causes the failure of an essential organs, hepatopancreas due to digestion, detoxification, lipid metabolism, and gill in which gases metabolism and energy budget take place. This study suggested that histomorphometry can serve as a useful tool in the recognizing harmful effects of toxic compounds on freshwater organisms, to establish the fundamental principles for morphometric measurements and acquire a numerical values of damage of toxicants in ecosystems. Concludingly, the results indicate that $H$. holandrii is a potential experimental indicator for aquatic pollution and could be a suitable species for examining water quality parameters.

\section{Conflict of Interest}

The authors declare no conflict of interest.

\section{References}

1. KLOBUČAR G.I.V., LAJTNER J., ERBEN R. Increase in number and size of kidney concretions as a result of PCP exposure in the freshwater snail Planorbarius corneus (Gastropoda, Pulmonata). Dis. Aquat. Org. 44 (2), 149, 2001.

2. LAJTNER J., ERBEN R., KLOBUČAR G.I.V., MAGUIRE I., LUCIĆ A. Histopathological changes in the gill of the fresh water snail Amphimelania holandri Fer. (Gastropoda: Prosobranchia) exposed to phenol. Period. biol. 105 (2), 157, 2003. 
3. ŠPOLJAR M., LAJTNER J., PRIMC-HABDIJA B. The effect of sodium pentachlorophenolate on histopathological changes in the digestive gland of Amphimelania holandri (Gastropoda, Prosobranchia). Biologia, Bratislava. 60 (2), 201, 2005.

4. BABIŃSKA I. Structural Lesions of Tissues and Cells Influenced by Environmental Pollution. In Influence of the pesticide dump on the environment (Contemp. Probl. Manag. Environ. Protec. 5: 121-131.), Skibniewska K.A., Ed, Publisher: University of Warmia and Mazury in Olsztyn, Olsztyn, Volume 5, 121, 2010.

5. MCLEAN D., ENG A., 't MANNETJE A., WALLS C., DRYSON E., CHENG S., WONG K., PEARCE N. 2007. Health outcomes in former New Zealand timber workers exposed to pentachlorophenol (PCP). Technical Report No. 20. Wellington: CPHR, 2007.

6. ZHENG W., YU H., WANG X., QU W. Systematic review of pentachlorophenol occurrence in the environment and in humans in China: Not a negligible health risk due to the re-emergence of schistosomiasis. Environ. Int. 42, 105, 2012.

7. World Health Organization. Regional Office for Europe. 2003. Health risks of persistent organic pollutants from long-range transboundary air pollution. Copenhagen: WHO Regional Office for Europe. https://apps.who.int/iris/ handle/10665/107471

8. CZAPLICKA M. Sources and transformations of chlorophenols in the natural environment. Sci. Tot. Environ. 322 (1-3), 21, 2004.

9. IGBINOSA E.O., ODJADJARE E.E., CHIGOR V.N., IGBINOSA I.H., EMOGHENE A.O., EKHAISE F.O., IGIEHON N.O., IDEMUDIA O.G. Toxicological Profile of Chlorophenols and Their Derivatives in the Environment: The Public Health Perspective. Sci. World J. 2013, Article ID 460215, 11 pages, 2013. https://doi. org $/ 10.1155 / 2013 / 460215$

10. ZHENG M.H., ZHANG B., BAO Z.C., YANG H., XU X.B. Analysis of Pentachlorophenol from Water, Sediments, and Fish Bile of Dongting Lake in China. Bull. Environ. Contam. Toxicol. 64 (16), 2000. https://doi.org/10.1007/ s001289910003

11. KUMAR B., KUMAR VERMA V., MISHRA M., PIYUSH., KAKKAR V., TIWARI A., KUMAR S., PRAKASH YADAV V., GARGAVA P. Assessment of persistent organic pollutants in soil and sediments from an urbanized flood plain area. Environ. Geochem. Health $\mathbf{4 3}$ (9), 3375, 2021. https://doi.org/10.1007/s10653-021-008399. 2021

12. MUTHUKUMARAVEL K., VASANTHI N., STALIN A., ALAM L., SANTHANABHARATHI B., MUSTHAFA M.S. Sublethal effects of phenol on histology of selected organs of freshwater fish Mystus vittatus. Environ. Sci. Pollut. Res. 28 (11), 13752, 2021.

13. YANG Y., XIAO Y., LI M., JI F., HU C., CUI Y. Evaluation of Complex Toxicity of Canbon Nanotubes and Sodium Pentachlorophenol Based on Earthworm Coelomocytes Test. PLoS ONE 12 (1), e0170092., 2017. https://doi.org/10.1371/journal.pone.0170092

14. ZHANG X., XIONG L., LIU Y., DENG C., MAO S. Histopathological and estrogen effect of pentachlorophenol on the rare minnow (Gobiocypris rarus). Fish Physiol. Biochem. 40 (3), 805, 2014.

15. BESSER J.M., DORMAN R.A., HARDESTY D.L., INGERSOLL C.G. Survival and Growth of Freshwater Pulmonate and Nonpulmonate Snails in 28-Day Exposures to Copper, Ammonia, and Pentachlorophenol. Arch. Environ. Contam. Toxicol. 70, 321, 2016.

16. LIU Z., ZHANG H., TAO M., YANG S., WANG L., LIU Y., MA D., HE Z. Organochlorine Pesticides in Consumer Fish and Mollusks of Liaoning Province, China: Distribution and Human Exposure Implications. Arch. Environ. Contam. Toxicol. 59, 444, 2010.

17. LAWRENCE A.J., POULTER C. Impact of copper, pentachlorophenol and benzo[a]pyrene on the swimming efficiency and embryogenesis of the amphipod Chaetogammarus marinus. Mar. Ecol. Progr. Ser. 223, 213, 2001.

18. WEIS J.S., CRISTINI A., RAO K.R. Effects of Pollutants on Molting and Regeneration in Crustacea. Am. Zool. 32 (3), 495, 2015.

19. BEIRAS R., TATO T. Marine environmental risk assessment and acute water quality criterion for pentachlorophenol in coastal waters. Ecotoxicology. 27, 803,2018

20. GOMOT-DE VAUFLEURY A. Standardized growth toxicity testing $(\mathrm{Cu}, \mathrm{Zn}, \mathrm{Pb}$, and Pentachlorophenol) with Helix aspersa. Ecotoxiol. Environ. Saf. 46 (1), 41, 2000.

21. MARIGÓMEZ I., SOTO M., CAJARAVILLE M.P., ANGULO E., GIAMBERINI L. Cellular and subcellular distribution of metals in molluscs. Microsc. Res. Tech. 56 (5), 358, 2002.

22. HAMED S.S., ABDELMEGUIED N.E., ESSAWY A.E., RADWAN M.A., HEGAZY A.E. Histological and Ultrastructural Changes Induced by Two Carbamate Molluscicides on the Digestive Gland of Eobania vermiculata. J. Biol. Sci. 7 (6), 1017, 2007.

23. OTLUDIL B., AYAZ S. Effect of Copper Sulphate $\left(\mathrm{CuSO}_{4}\right)$ on Freshwater Snail, Physa acuta Draparnaud, 1805: A Histopathological Evaluation. Bull. Environ. Contam. Toxicol. 104 (6), 738, 2020.

24. LOBO-DA-CUNHA A. Structure and function of the digestive system in molluscs. Cell Tissue Res. 377 (3), 475, 2019.

25. CUMMING H., HERBERT N.A. Gill structural change in response to turbidity has no effect on the oxygen uptake of a juvenile sparid fish. Conserv. Physiol. 4 (1), 2016. cow033, https://doi.org/10.1093/conphys/cow033

26. MARKOVIĆ V., ATANACKOVIĆ A., TUBIĆ, B., VASILJEVIĆ B., KRAČUN M., TOMOVIĆ J., NIKOLIĆ V., PAUNOVIĆ M. Indicative status assessment of the Danube River (Iron Gate sector 849 - 1,077 rkm) based on the aquatic macroinvertebrates. Water Research and Management. 2 (2), 41, 2012.

27. Guidelines for drinking-water quality: fourth edition incorporating the first addendum. Geneva: World Health Organization; 2017. Licence: CC BY-NC-SA 3.0 IGO.

28. CHEN Y., YU S., TANG S., LI Y., LIU H., ZHANG X., SU G., LI B., YU H., GIESY J. P. Site-specific water quality criteria for aquatic ecosystems: A case study of pentachlorophenol for Tai Lake, China. Sci. Total Environ. 541, 65, 2016.

29. GE J., PAN J., FEI Z., WU G., GIESY J.P. Concentrations of pentachlorophenol (PCP) in fish and shrimp in Jiangsu Province, China. Chemosphere. 69 (1), 164, 2007.

30. CARRASQUER G., LI M., YANG S., SCHWARTZ M., DINNO M.A. Effect of pentachlorophenol (PCP) on frog cornea epithelium. Proc. Soc. Exp. Biol. Med. 222 (2), 139, 1999.

31. CENGIZ E.I., YILDIRIM M.Z., OTLUDIL B., UNLÜ E. Histopathological effects of Thiodan ${ }^{\circledR}$ on the freshwater 
snail, Galba truncatula (Gastropoda, Pulmonata). J. Appl. Toxicol. 25 (6), 464, 2005.

32. BONOU S., SAGBO E., AUBRY C., CHARVILLAT C., BEN-NISSAN B., CAZALBOU S. Conversion of snail shells (Achatina achatina) acclimatized in Benin to calcium phosphate for medical and engineering use. J. Aust. Ceram. Soc. 55 (4), 1177, 2019.

33. DUMMEE V., TANHAN P., KRUATRACHUE M., DAMRONGPHOL P., POKETHITIYOOK P. Histopathological changes in snail, Pomacea canaliculata, exposed to sub-lethal copper sulfate concentrations. Ecotoxicol. Environ. Saf. 122, 290, 2015.
34. JUDGER B.-E., ERTAN H., BOHL S., LEE M., MARQUIS C.P., MANEFIELD M. Organohalide Respiring Bacteria and Reductive Dehalogenases: Key Tools in Organohalide Bioremediation. Front. Microbiol. 7, Article 249, 2016.

35. LOPEZ-ECHARTEA E., MACEK T., DEMNEROVA K., UHLIK O. Bacterial Biotransformation of Pentachlorophenol and Micropollutants Formed during Its Production Process. Int. J. Environ. Res. Public Health. 13 (11), 1146, 2016. 